\title{
Successful shared breeding in an artificial nest-box by Common Swift Apus apus and Common Redstart Phoenicurus phoenicurus
}

\author{
Lyckade häckningar i samma holk av tornseglare Apus apus och rödstjärt \\ Phoenicurus phoenicurus
}

\author{
MAXIME PIRIO, ARNE ANDERSSON \& SUSANNE ÅKESSON
}

\begin{abstract}
During the spring 2015, a pair of Common Redstarts Phoenicurus phoenicurus successfully raised a fivechick brood in an artificial nest-box designed for and occupied by a pair of Common Swifts Apus apus in southern Sweden. The breeding was monitored by a nest-box camera, which recorded close interactions between the two species. The Common Redstarts initiated the breeding first and had young in the nest when the Common Swifts arrived and initiated breeding by laying their eggs in a nearby nest cup. The breeding overlapped by 15 days

between the second and the fourth week of June when all five of the nestlings of the Common Redstart fledged. The Common Swifts raised two young which fledged in early August.

Maxime Pirio, Arne Andersson, and Susanne Akesson, Centre for Animal Movement Research, Department of Biology, Ecology Building, SE-223 62 LUND, Sweden; Corresponding author: Susanne Akesson (Susanne.Akesson@biol.lu.se)
\end{abstract}

Received 14 September 2015, Accepted 22 October 2015, Editor: S. Svensson

The Common Swift Apus apus (Swift below) is a migratory species spending the non-breeding season in West and Central Africa (Åkesson et al. 2012). The breeding range covers most of continental and northern Europe, where it reaches as far south as North Africa and east to China (Cramp \& Brooks 1985). At Lund University in South Sweden, 144 nest-boxes designed for Swifts have been incorporated in the upper part of the wall at the fourth floor of the Ecology Building. The nest-boxes can be inspected from the inside of the building by opening a door leading to six nest-boxes jointly built in each section (Figure 1a). To investigate the breeding success of the Swifts and to monitor their reproduction schedule, thirteen cameras have been installed in nest-boxes with complete nest cups built by Swifts. The inner dimensions of the nestboxes are the following: height $228 \mathrm{~mm}$, width 309 $\mathrm{mm}$, depth $485 \mathrm{~mm}$, and entrance hole diameter $50 \mathrm{~mm}$ (Figure 1b).

Breeding pairs of Swifts most often are faithful to their nests, which has been confirmed also at the colony at the Ecology Building at Lund University. The Swift is known to be aggressive towards conspecifics as a consequence of nest competition. This aggressive behaviour, however, is frequently directed towards other hole-nesting species such as House Sparrow Passer domesticus, Common Starling Sturnus vulgaris, Black Redstart Phoenicurus ochruros and Common Redstart (Redstart below) (Genton 2009). However, the first two species are much more prone to fight back and may exclude the Swifts out of the focal nest. As the Swift is a late arriving migrant, the breeding sites and nest-boxes they use are available for other hole-nesting species until mid-May in south Sweden. Thus, when the Swifts return from their wintering grounds, the nesting sites may already be occupied by other species sharing the same preference for breeding sites. European Starlings have been reported to outcompete in many cases the Swifts (Cramp \& Brooks 1985). There is more information about the interaction between House Sparrows and Swifts because it happens more frequently. According to the Swift colony size, the response of that species against the House Sparrows using the nests is quite different. In some cases in the small colonies (less than 10-15 pairs), the House Sparrow usually outcompetes the Swift from the nest. On the other hand, if the swift colony contains more than 10-15 pairs, they are more able to eject the former species out of their nests. However, their impact can 


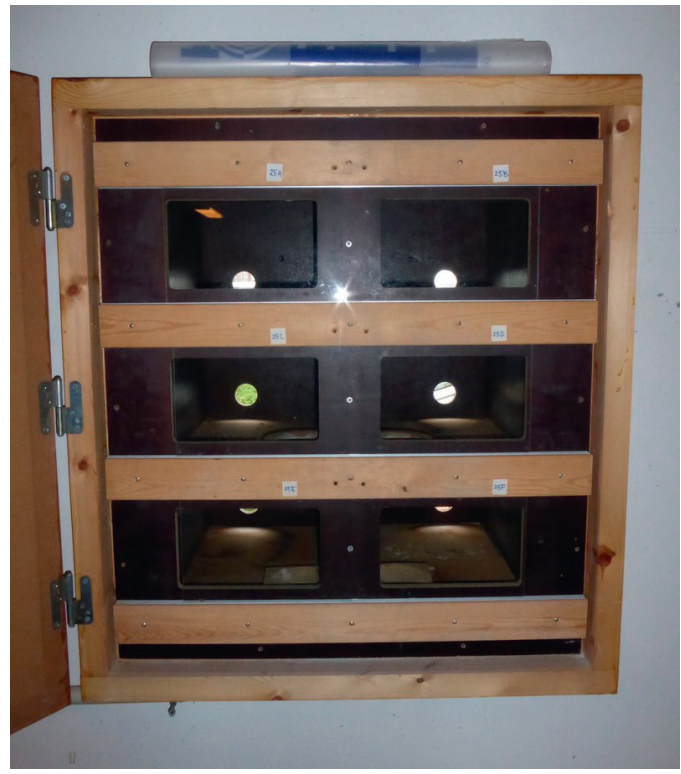

Figure 1a: A photo of the nest box section including six independent boxes as seen from the inside.

Foto av en sektion med sex oberoende holkar sedda från insidan.

still hold because they can destroy the fresh eggs by beating or removing them from the nests when the adults are not present in the nest, avoiding cold spells or bad weather (Genton 2009). In that case, the Swifts lay a replacement clutch. The swift does not always expel the other individuals out of the nest and can occupy the same nest that the other species breeding at the same time. This behaviour has been described by Verschuren (1947, in Brackbill 1952) where House Sparrows and Swifts were nesting in the same hole in a wall. Swifts may also manage to find another breeding site if their own cavity is already occupied when they come back from wintering in Africa, even though the swifts are conspicuously dominant in the nesting site competition. Genton (2009) noted this behaviour when a Swift managed to find another nest-box without destroying a Black Redstart brood located in the nest-box of interest, even after having visited the box for several days.

In our case, the Redstart pair successfully fledged five young in the same nest-box where a Swift pair laid two eggs upon return, and without killing any of the redstart young present. This event has been noted thanks to the nest-box camera which has been installed before the breeding season.

We recorded the following reproductive schedules of the two species observed. The Redstart

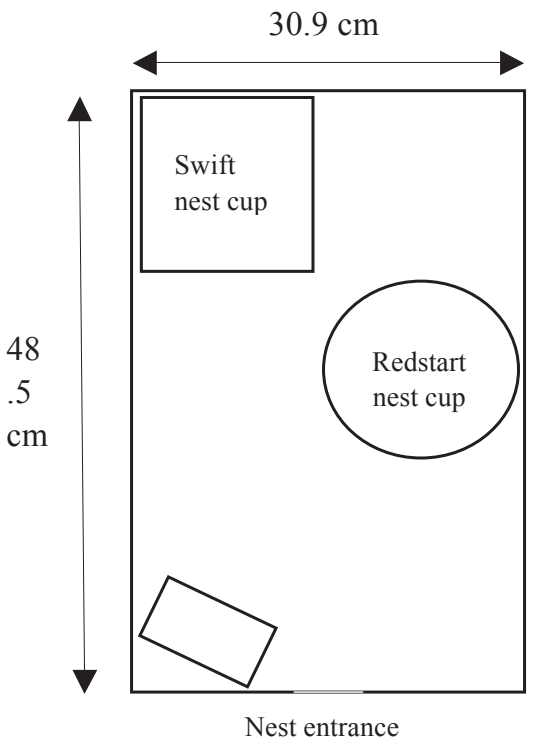

Figure 1b: Schematic drawing of the nest-box with the camera including position of the nest cups of the Common Redstart and the Common Swift. Camera position is indicated by the squared box. Size of nest-box and position of nest entrance is indicated.

Skiss av holken med kamera samt läget för boskålarna av rödstjärt och tornseglare. Kamerans position markeras av rektangeln $i$ nedre vänstra hörnet. Holkens mått och ingångshålets läge finns angivet.

started to visit the nest-box on the fourteenth of May and began to build its nest on the sixteenth. As the camera was at the beginning only oriented towards the Swift nest cup, some of the events were determined thanks to information on the reproductive schedule of the Redstart reported in the literature. The incubation probably started on the twenty-seventh or twenty-eighth of May. Four out of the five chicks fledged the twenty-third of June, whereas the last one fledged on the following morning at 5:50 a.m. As there were only eggs on the ninth of June and, according to Cramp \& Brooks (1988), the hatching date was probably on the tenth of June (fledging period: fourteen to fifteen days). In Redstarts, the hatching event is usually synchronous.

The pair of Swifts arrived on the tenth of June and returned to use the Swift nest cup (Figure 2-4). The laying dates were on the eighteenth and on the twentieth of June. Between their arrival and the first laying event, the Swifts spent all the night roosting in the box and visited several times the nest-box during daytime. There was a breeding of Swifts in the same nest box the previous year, and 


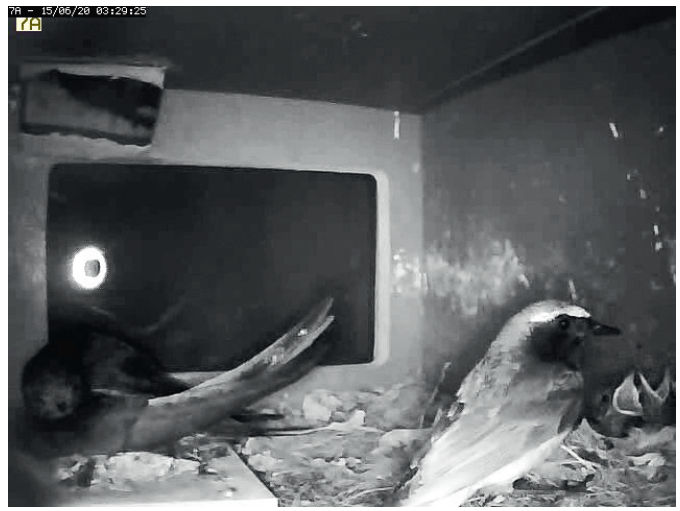

Figure 2. Photo of Common Redstart nestlings in their nest and Common Swift sitting on the swift nest cup. The parent Common Redstarts were sucessfully feeding their young in the box as the Common swift was incubating.

Rödstjärtungarna $i$ sin boskål medan en tornseglare ligger $i$ sitt bo. Rödstjärtföräldrarna kunde framgångsrikt mata sina ungar medan tornseglaren ruvade.

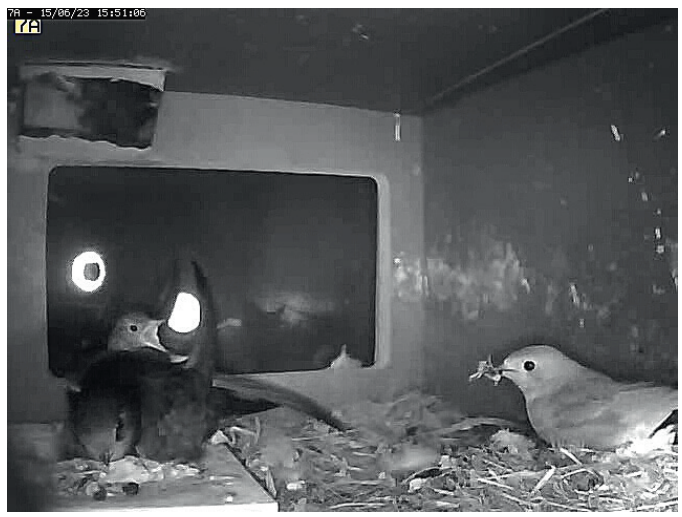

Figure 3. Common Redstart nestlings in Common Swift nest, where the adult incubating Common Swift was sometimes seen preening the redstart young.

Rödstjärtungar $i$ tornseglarboet, där den adulta tornseglaren ibland sågs plocka bland rödstjärtungens fjädrar.

presumably at least one or both individuals were the same. On some days, when the Redstart adults were out of the nest to find food, the Swifts seemed to have a look inside the strangers' nest, especially on the last days. Nevertheless, it is hard to determine if they at all attacked the redstart chicks, and we could not find any dead chicks after inspection. Another interesting aspect happened the second to last day (twenty-third of May) when both species shared the nest-box. The last three chicks visited the Swift's nest around 2 p.m. and stayed there for five hours whilst the adult Swift at the same time was incubating eggs in its own nest. At some instances we noted that the Swift was even preening

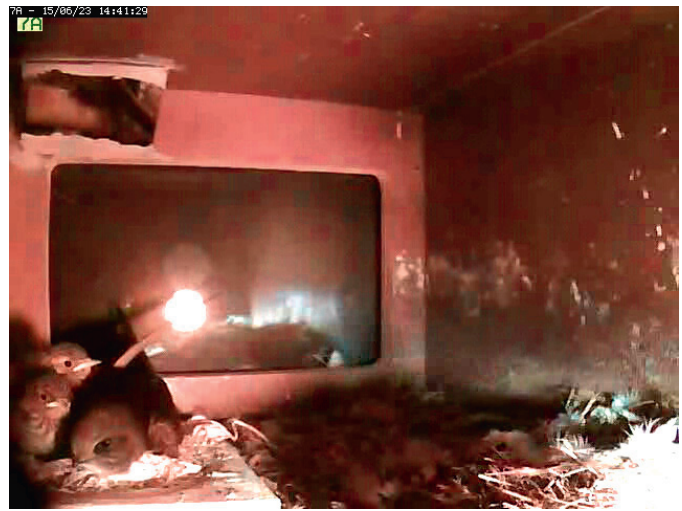

Figure 4. The Common Redstart nestlings spent substantial time in the Common Swift nest without triggering agressive behaviour from the adult swift.

Rödstjärtens ungar tillbringade rätt mycket tid i tornseglarens bo utan något aggressivt beteende från tornseglarens sida.

the Redstart young. Despite this close interaction, the Redstart parents were able to feed their young eight out of ten times without being expelled by the Swifts.

Apart from the House Sparrow, the interaction during the breeding season between the Swift and another hole-nesting species does seem to be rare (see references given above). The event related above is quite interesting as the Redstart successfully raised its brood while the Swift probably easily would be able to outcompete it. Later in the same season the Swifts successfully raised a brood in the same box, which fledged 19 August. The size of the nest-box presumable made is possible for this joint two-species breeding to occur, as the size of the box permitted two independent nests to be built and the Redstarts choose to build their nest near the entrance, while the Swifts prefer to build as far as possible from the entrance, in the darkest corner of the box (Figure 1b). By this difference in nest position preference within the box, we believe the immediate competition for space was reduced, and a joint successful breeding involving the Redstart and the Swift was possible.

\section{References}

Åkesson, S., Klaassen, R., Holmgren, J. Fox, J.W. \& Hedenström, A. 2012. Migration routes and strategies in a highly aerial migrant, the Common Swift Apus apus, revealed by light-level geolocators. PLOS ONE. 7(7). e41195. doi:10.1371/journal.pone.0041195.

Brackbill, H. 1952. A joint nesting of Cardinals and Song Sparrows. The Auk. 69(3): 302-307.

Cramp, S. \& Brooks, D.J. 1985. Handbook of the birds of 
Europe, the Middle East and North Africa. The birds of the western Palearctic, Vol. IV: Terns to woodpeckers. Oxford University Press.

Cramp, S. \& Brooks, D.J. 1988. Handbook of the birds of Europe, the Middle East and North Africa. The birds of the western Palearctic, Vol. V: Tyrant Flycatchers to Thrushes. Oxford University Press.

Genton, B. 2009. Relations interspécifiques du Martinet noir Apus apus avec le Moineau domestique Passer domesticus : Exemple d'aménagements novateurs en faveur du Martinet noir. Nos oiseaux 56: 67-86.

\section{Sammanfattning}

Under 2015 lyckades ett rödstjärtpar att föda upp ungar i samma holk som tornseglare i en tornseglarkoloni med artificella boplatser i södra Sverige.
Häckningen övervakades med hjälp av en kamera installerad i holken, där nära kontakt mellan de två arterna kunde bekräftas. Rödstjärtarna inledde sin häckning innan tornseglarna återvände till den holk de häckat i tidigare år. Då tornseglarna anlände inledde de äggläggning och ruvning i normal ordning och utnyttjade den boskål de använt tidigare år. De två arterna hade skilda boskålar i holken, men när rödstjärtungarna började röra sig runt i holken uppstod närmare kontakt, då bland annat tornseglarna kunde konstateras putsa rödstjärtungarna. Häckningarna överlappade med 15 dagar mellan den andra och fjärde veckan i juni, då samtliga fem rödstjärtungar lämnade boet. Tornseglarna lyckades föda upp två ungar flygga i början av augusti. 